\title{
INCORPORATION OF HUMANITARIAN PROGRAMS: UKRAINE'S EXPERIENCE
}

- Would you kindly tell readers of our issue about the history of creation of the International Committee of the Red Cross and major areas of its activity?

- The history of establishment of the International Committee of the Red Cross is rather interesting. It was created in the $19^{\text {th }}$ century, starting with a Swiss man, who travelled to Italy where there was at that time a war between the allied France and Sardinian armies and the Austrian army, he was shocked to see how many wounded soldiers in Solferino did not receive any care. The name of this Swiss is Henry Dunant, a banker, who was so affected that he decided he had first to help those soldiers from both sides. Later he wrote a book, expressing the idea that in any war the wounded must be treated and that in all countries there have to be some organizations dealing with this issue. To represent such organizations he designed a sign of Red Cross that was associated with healthcare and is a reverse of the Swiss flag. The book was called A Memory of Solferino and shortly after, Mr. Dunant together with four other Swiss eminent persons established in 1863 the so-called Permanent International Committee, which then became the International Committee of the Red Cross. The Committee contacted the powers of the time and managed to have them organize an international conference to adopt the First Geneva Convention on the treatment of the wounded on the battlefields. In fact, it was the first case in modern history of a substantial initiative from private persons, which managed to convince states. This Committee has gradually developed and expended. Its headquarters is based in Geneva and the governance comprise around 20 people who are all Swiss nationals as specified in the statutes. Yet, the administration is formed of different nationalities. For example, the international staff of the ICRC in Ukraine has about 20 nationalities. Over time, the organization has started to deploy quite large humanitarian operations, a most significant development occurring following the conflict in Indochina, particularly Cambodia in the 1980s.

Today, the International Committee of the Red Cross is a very large organization with about 2,000 international staff, 18,000 national staff and global budget of about 2 billion Swiss francs. In the end of May 2018, it celebrates the 155-year anniversary. It is clear that charity activities have been undertaken long ago in the past in different parts of the world but with the establishment of the ICRC and the adoption of the First Geneva Convention, the modern stage of humanitari- 


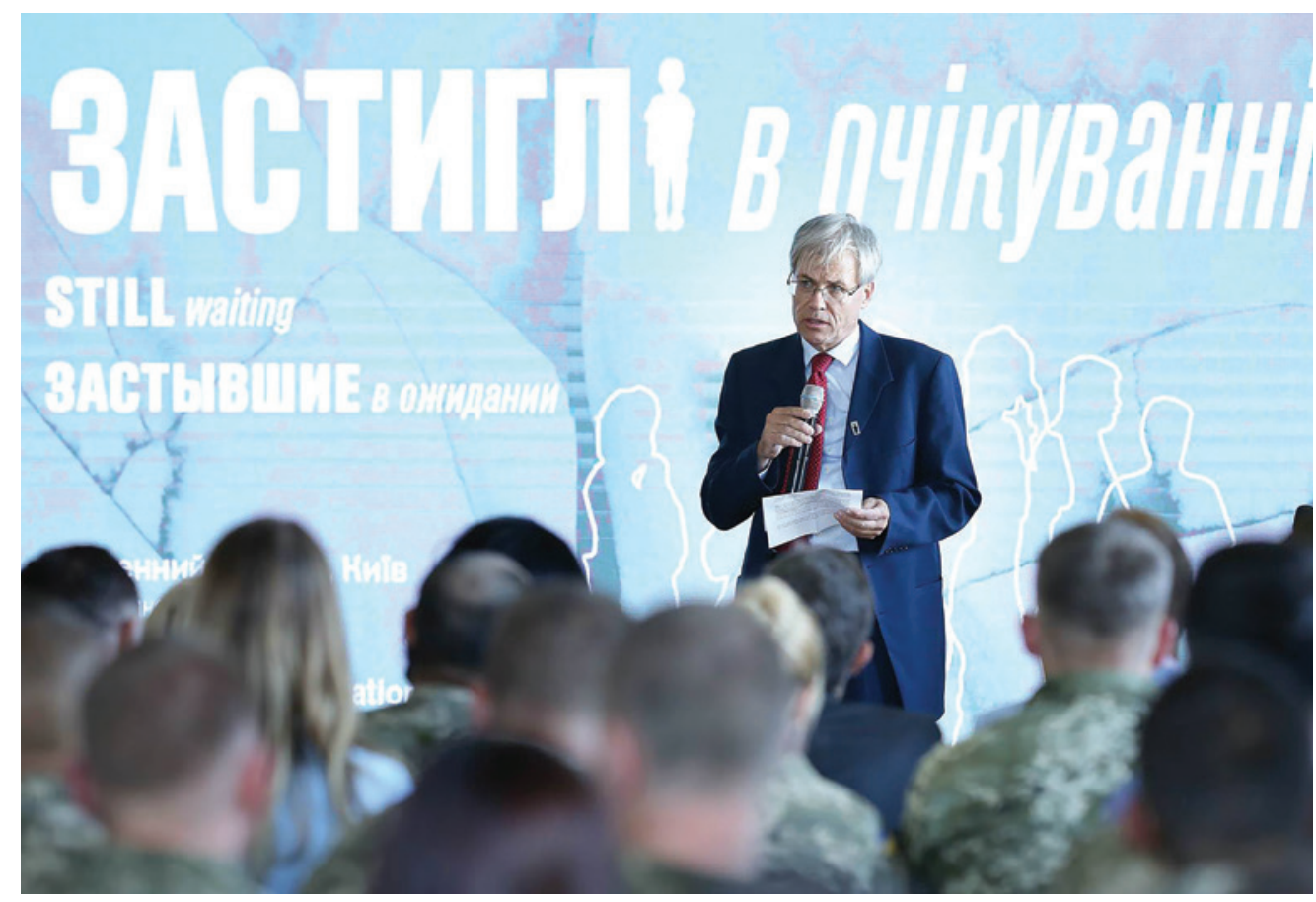

Алан Ешліманн під час промови на церемонії відкриття інсталяції «Застиглі в очікуванні», присвяченій сім'ям тих, чиї близькі зникли безвісти через збройний конфлікт на Сході України

Alain Aeschlimann delivers a speech at the opening of the installation "Frozen in waiting", dedicated to the families of those whose relatives have disappeared due to the armed conflict in the East of Ukraine

an aid started. Initially and this remains its distinctive feature, the International Committee of the Red Cross is a neutral, independent and impartial organization. When founding it, Henry Dunant had the idea of having in all countries a relief organization, which could act between sides in a conflict. The central element of the ICRC is to be accepted by all and to become a kind of bridge between sides, which in international conflicts means also to be able to visit and assess the situation of prisoners from the other side. Therefore, the issue of caring for the wounded soldiers and prisoners was from the very beginning of the organization's functioning, which has eventually enhanced into the treatment of all people having health problems in situations of conflict and different categories of violence. There was also the expansion of covering the needs with regard to food, which was largely started with the conflict in Biafra, where people suffered from famine. Then the distribution of seeds, agricultural programs and other social-economic activities were also added to our program. We also started to realize that water is key in the survival of populations, so there were more and more activities for providing drinking water, facilitating the establishment of dwells and pipelines, etc. In addition, the ICRC has developed activities related to the issue of people missing because of the conflict. This started with the idea to allow families separated 


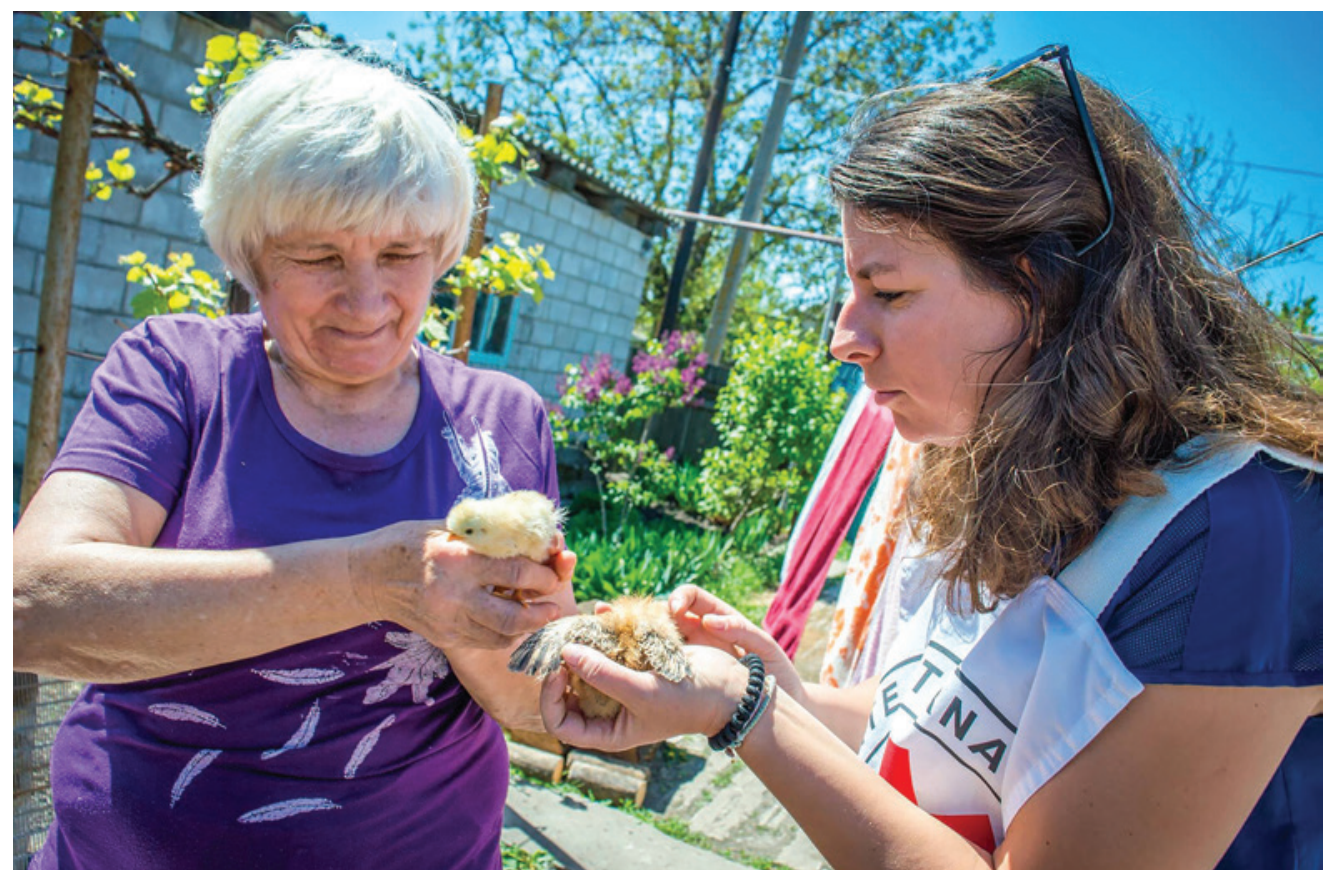

Навесні 2018 року 168 сімей у селах Донеччини одержали інкубатори для розведення птииі In spring 2018, 168 families from Donetsk region villages obtained hatchers for breeding poultry

by conflicts to exchange news and we were acting as intermediaries in bringing news from one side to the other, particularly from prisoners. Another focus area was to assist in identification of mortal remains, so that families receive the information whether a missing person is still alive or not. It is very often in a conflict that there are many casualties and mass graves, so it is impossible to recover them immediately because of the security situation. It usually happens that a family need to wait some time to recover and bury the body. Later on the ICRC has also started to develop other activities related to mines, as mine risk education, and many activities on informing population and the danger caused by mines and non-exploded ordnances and strengthening capacities of authorities to conduct humanitarian demining.

All over history, since the adoption of the First Geneva Convention, the International Committee of the Red Cross has continued to work on international humanitarian law and interact with states for its development. After each major conflict, most notably the First World War, the Second World War, the Vietnam War, new treaties and protocols were proposed and adopted. In this context, the ICRC has a strong legal department, which tries to analyze particularities of conflicts and defines whether the legal framework is sufficient or it should be adapted and strengthened to new means of warfare in order to improve protection and assistance to victims. Accordingly, this legal aspect is also an important part of the organization activities. This means that the ICRC works on, promotes 
and keeps authorities as well as armed forces informed about the international humanitarian law. For this reason we conduct large programs on training and dissemination. Most recently, the ICRC has developed activities dealing with psychological consequences of conflicts, in the framework of which there are psychosocial and mental health programs aimed at supporting people, who are psychologically affected and sometimes traumatized by this type of situation. To summarize, the International Committee of the Red Cross has a rather large scope of activities that are fully linked with the situation of conflict or internal violence and strives to cover all the related needs, focusing not only on certain categories of people, but dealing with any person according to his or her needs. At the same time, the organization's activities are complementary to the governmental authorities, which have the first and foremost responsibility.

- The International Committee of the Red Cross is known to operate in Ukraine since April 2014 - the beginning of the military conflict in eastern Ukraine. What in your opinion has changed over the four years of the Committee service in the country?

- As a matter of fact, until 2012, the ICRC had a regional office in Ukraine, which was opened shortly after the country's independence. At that time, its activity covered Belarus, Moldova, Poland, and operated mostly to promote international humanitarian law and cooperate with the national societies of the Red Cross. When it was closed in 2012, no one expected the ICRC would be so much involved after two years. When the organization resumed its activity in February 2014, there were only five or six people, but then it has been expanded. Today, we have offices in Donetsk, Luhansk, Sloviansk, Severodonetsk, Mariupol and Odesa. Yet, in 2014 it was extremely difficult for us to anticipate what would happen and we always felt behind the events. The ICRC's deployment was also impacted by the loss of a colleague, who died in Donetsk on October 2, 2017. It took the staff a couple of months to catch up with the situation. At last, we settled and managed to implement nearly all types of programs. What the International Committee of the Red Cross does is tries to understand as much as possible the dynamics of the conflicts, different sensitivities and particularities of the context. There are some specific and notable aspects in our work in Ukraine. The first is that the conflict takes place mainly between the same people: there are a lot of Donbas residents, who have their families in the capital or other oblast, a very large number of people move from one side on the contact line to the other. There is no basic difference concerning ethnic groups or language, as it may be the case was in some other countries. The conflict is also highly polarized and politicized. This gives the ICRC some challenges, as we need to be accepted by all and to be perceived as totally neutral and impartial organization. Therefore, it is always rather difficult to prevent our activities from being politically used. What is also very striking is how unnoticeable in Kyiv is the conflict that is actually not so far geographically. This fact generates several new realities in the country. 
- The organization representatives are active both in the Ukrainian and occupied territories. Are there any crucial differences in the needs of the two parties to the conflict? How the ICRC representatives are treated in the conflict zones?

- Our employees are indeed present on both sides: the government-controlled and non-government controlled areas. We do the same in many countries as in Syria, for example. What we don't do without agreement of a sovereign government is a so-called cross-border. The ICRC runs its operations and has its logistic chain from the governmental side of the line of contact; we transfer humanitarian cargo to uncontrolled areas, where the ICRC representatives contact the persons, who are in charge, and have regular negotiations for access and implementation of programs. In general, we are developing the same type of programs on each side. However, it is clear that the situation in Donetsk and Luhansk uncontrolled areas is different: people there have more needs, for example, for medicine, especially for chronic diseases. For this reason, shortly after beginning of its activities, the ICRC has started to support patients with kidney problems, who require hemodialysis, or patients with diabetes, who need insulin. But again, at large we are doing the same type of work, so it is difficult to say which side has more needs, all the more so the contact line may move, considering the position of mines or other remnants of war.

- You have already worked in Iraq, Angola, Peru, Israel, Ethiopia and you have been working in Ukraine since May 2015. What you consider a challenge and what has appeared to be a pleasure in working in our country?

- What is interesting, yet challenging, for me in working in Ukraine is how quickly the situation is changing, considering reforms and transitory situation of the country. Despite the fact that the contact line does not move much and the conflict is protracted and has not had intensive shelling or shooting for several months, the ICRC has to stay alert in order to react swiftly to all events that may occur. I personally come from a rather stable country, where big news happen very rarely. On the contrary, here something new happens nearly every day, which is very interesting for an observer. At the same time, what is particularly difficult for our team is the attitude people may have towards those living in the east, and opposing the provision of help for them. Many people do not have a choice - their home is there. This reaction may sometimes complicate our task, as we are working for all civilians and it is important to maintain connection between the people. Today, this problem is more significant, than it was three years ago. People on the other side of the contact line have the same needs, not exclusively medicine or food, but also the right to live in a proper and dignified way.

The issue of social media and communication is very influential in this context, so it is important for an organization to be aware of it and the consequences reputation-wise. If the products or services we provide are of low quality are provided or the work is done in a non-professional way, the cred- 


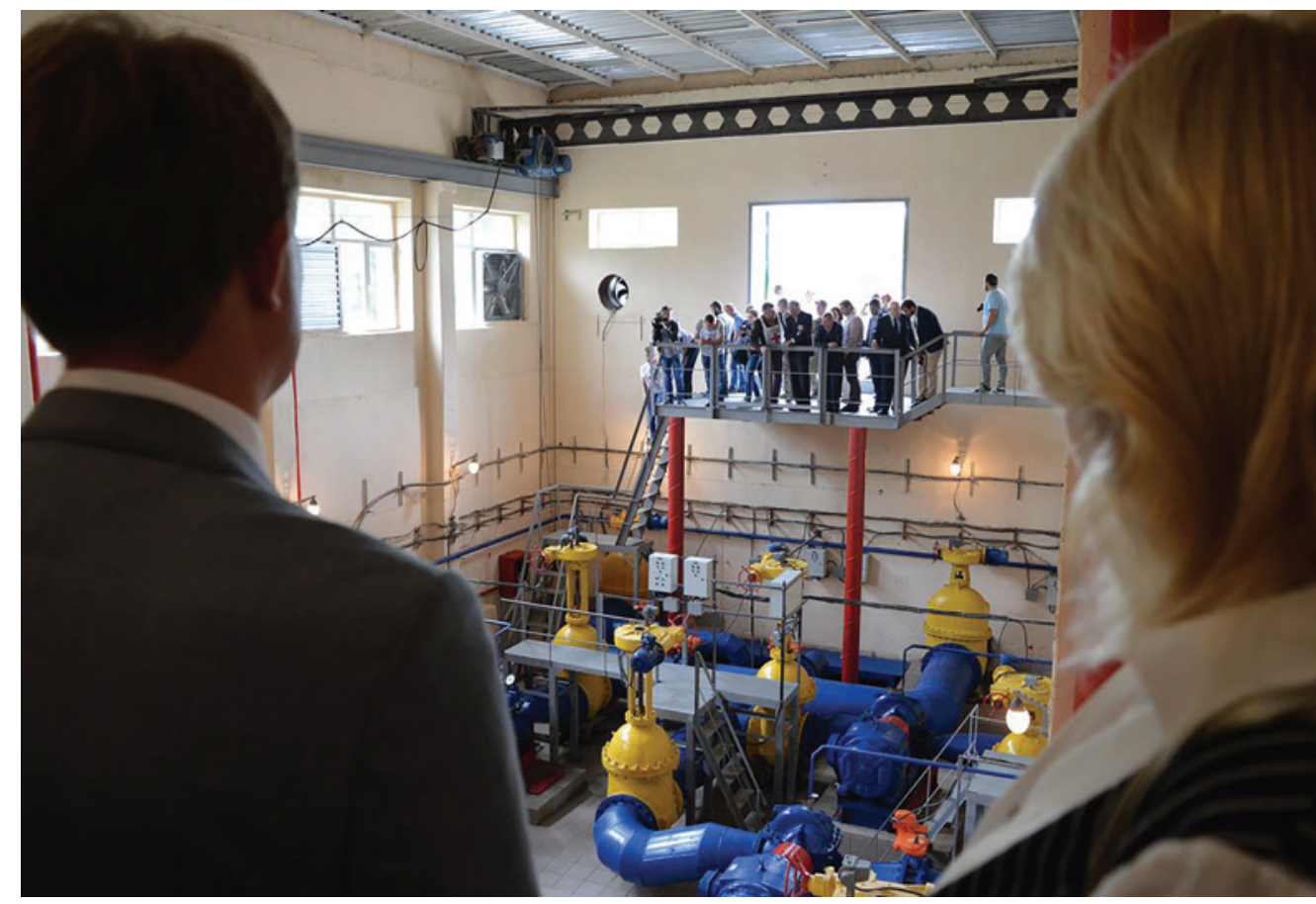

Відкриття Карлівської насосної станції після реконструкиї за підтримки Міжнародного комітету Червоного Хреста

Opening of Karlivka pump station after the reconstruction under the assistance of the International Committee of the Red Cross

ibility may be easily lost, the outcome of which eventually becoming toxic through the media. There are still some security concerns, taking into account that there are still regular shelling in some areas and that we about 30-40 field trips to the contact line daily.

Luckily, there are in Ukraine many interlocutors, with whom we have very substantial discussions and hopefully reach understanding. For me, it provides an opportunity to develop ideas for finding agreement between all sides. Still, it is quite interesting to have such an exchange and I am personally impressed by the level of interlocutors I deal with.

I enjoy living in Ukraine, especially now, when we are moving towards summer. It is clear that the International Committee of the Red Cross is working in many countries, where facilities are broken or not existing at all, so as I mentioned before it is pleasing that people in other regions have a normal life and are not affected by the war in the east. Considering that the ICRC representatives dedicate their time to the victims, I am happy that they have chance to keep a personal balance in peaceful environment as here in Kyiv. This is the part I really appreciate. I also enjoy the culture: every day there are performances, concerts and exhibitions, which indeed helps a lot in coping with the challenges. 


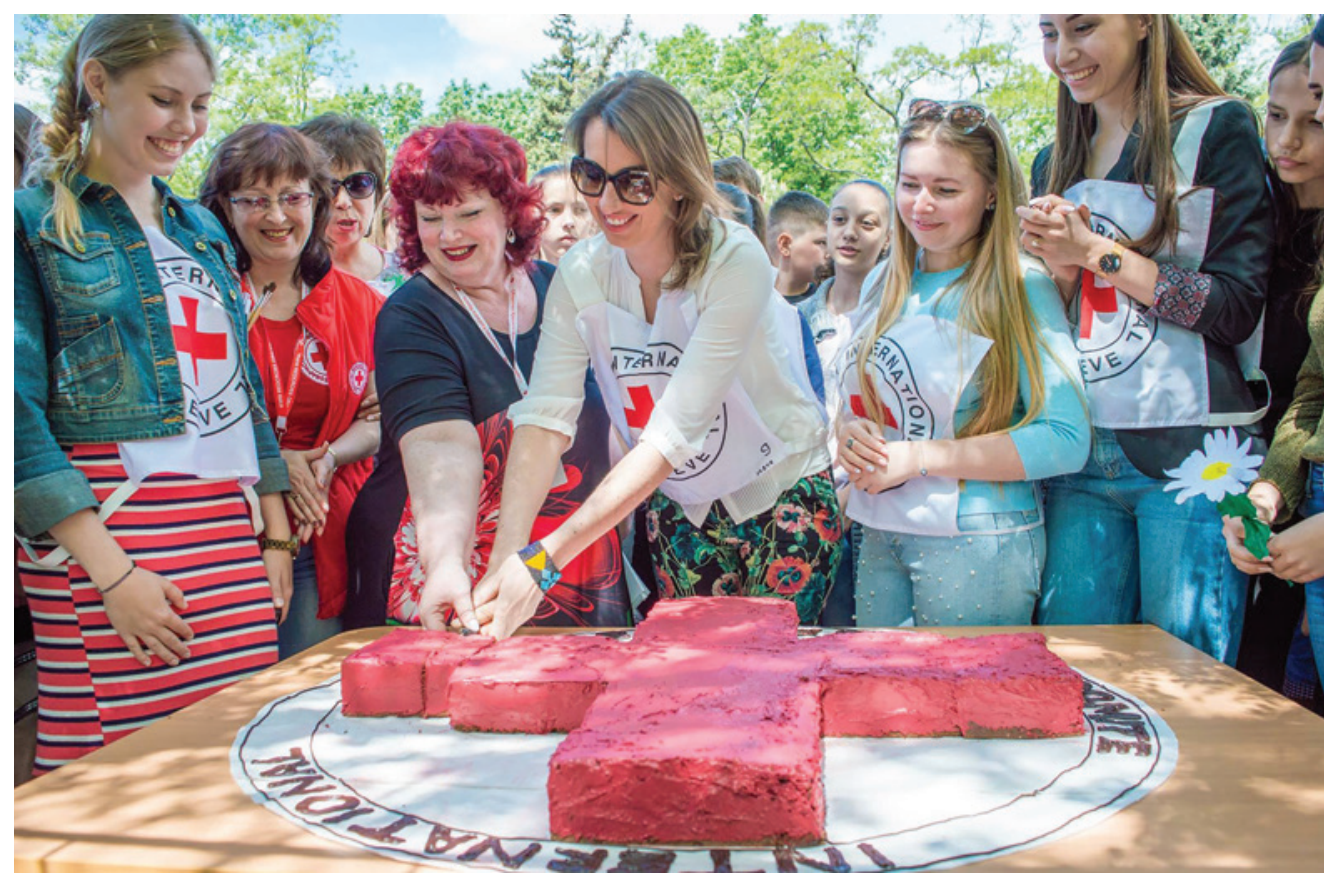

Святкування Дня Червоного Хреста та Червоного Півмісяия в Маріуполі. 31.05.2018 Celebration of the Red Cross and Red Crescent Day in Mariupol. 31.05.2018

- What is your perspective on the initiative of deploying a peacekeeping mission in the conflict zone in the eastern part of Ukraine?

- We do not have and position on this, as the decision of deploying as well as to where and how to do it is a political one. In this context, the International Committee of the Red Cross upholds any view, as it would be immediately assessed as the display of support of one or the other side. At the same time, we always welcome any kind of initiatives that might improve the situation and alleviate the suffering of the people. The possible successful deployment would definitely have an impact on both the needs of the population and our activities, so the ICRC carefully monitors what is happening. Anyway, in case the conflict is reduced, we will still have activities in other areas, like implementing programs on missing persons, facilitating the provision of water from one side to the other and relieving psychological consequences of the conflict. When I came to Ukraine in April 2015, I did not expect we would have such large operations in 2018, hence, the last years prove that it is rather difficult to make a clear projection. Nonetheless, we all hope for the best - success for the ICRC is when it can reduce its activities or even leave a country. In fact, the International Committee of the Red Cross has not left many countries for the last 50 years, as a conflict inevitably has long lasting consequences. For example, we are still active in the Balkans, namely Bosnia and Herzegovina, Serbia, Kosovo regarding missing persons and do psychological assistance. 
- Does the Committee encounter currently any issues with delivering humanitarian aid?

- To put it frankly, there are always some issues. At first, when we started, Ukraine did not have witnessed major humanitarian operations before: the last large-scale one was in Chornobyl. Accordingly, when the conflict started, the authorities had to learn what a large humanitarian action is and how to deal with humanitarian organizations. What also impedes is rather strong bureaucracy in Ukraine and at the beginning we had to strive for some procedures to be simplified, because it was difficult to fill all the forms in time, as it was necessary to deliver humanization aid immediately. Over time, all these have been adapted and now I can say that currently the ICRC has favourable conditions for working. Despite having occasionally some issues and discussions, globally we are very satisfied with what was achieved. Moreover, the ICRC representatives receive now a considerable amount of trust from all sides. I travel regularly to Donetsk and Luhansk, so I am well aware of it. Consequently, we need to be very careful to justify this trust. As a whole, I have got no complains about any particular obstacles in our activity for the time of staying, yet, certainly, there are always something that may be improved and developed. Notably, we are working on having access to detainees in Donetsk and Luhansk as well as a systematic access to those detained in Kyiv under the authority of the Security Service of Ukraine. But again, considering the whole environment and constraints, the International Committee of the Red Cross benefits from good working conditions.

- Would you name focus areas of the International Committee of the Red Cross activity in Ukraine for 2018 ?

- Traditionally, the annual planning is done in September or October. In general, the ICRC employees are active in consolidating what has already been done, but we are also developing more activities in regard to missing persons and expand psychosocial and mental health programs. Moreover, the focus on primary healthcare close to the contact line is put in more substantial way, than it was the case before. The ICRC puts together humanitarian assistance and some recovery activities. For instance, near the contact line on the side of the government, people need more means to resume economic activity, rather than food, providing that they feel safe. Therefore, we are active in encouraging demining and cleaning unexploded shells in the fields, and helping renovating public infrastructure. Hence, we are trying to develop the possibilities for small-scale business, livelihood, etc. Still, we keep in parallel all emergency response capacity in case of aggravation of the situation, as it was the case in Avdiivka last year. For this reason, it is important for the ICRC to have the capacity to react with the significant level of assistance, if something happens at the contact line. 
- To conclude, Mr. Ashliman, could you please tell about yourself? How has it happened that you have chosen this kind of profession? Do you manage to find leisure time, despite the busy schedule, and what are your favourite places in Ukraine?

- I started as a young lawyer wishing to do something positive for others and be abroad at the same time. So I planned to work for a humanitarian organization for a couple of years and then go back to work as a lawyer in my country. I applied for the ICRC and was selected. Initially, I was thinking to work at the organization for two years, but then realized I liked that job so much that I stayed, and now I have been with the ICRC for 31 years already. It is also clear that during all these years this type of activity has developed greatly and become much more professional. I enjoy being abroad and trying to understand problems a county faces, its history and people. It is an incredible experience to learn what lies behind the conflict, what are the priorities of the different sides, which gives an impression of being a little part of history.

I like staying in Ukraine, the environment here is very comfortable. I often do jogging. In the weekends, I like to go to the forest near Expo Centre and enjoy fresh air. As I have mentioned, it is very important to have a good balance between work and recreation, as our activity is indeed stressful. When you go to the contact line and see the people living there, it is noticeable how much they are thankful. I used to work in the environment, where people did no say thank you and expressed no visible acknowledgement of the work done. On the contrary, it is impressive in Ukraine that when you go to frontline villages, many elderly people come to speak with you and after two or three minutes burst into tears, expressing their gratitude. Very often, these people say that it is not about what we bring, but just about the fact that we are there and show them that they are not forgotten. To see how much people are thankful for what is done is for me incredibly valuable. Certainly, we have occasionally some frustrations, because we always think we should do more, but this acknowledgement as well as positive achievements in different areas is a great source of motivation for the ICRC team. However, we need to be modest, since what we bring is not so important globally, but rather symbolically significant. 